\title{
Public Expenditure and Human Development in Nigeria in the last decade, composition and distributional impacts
}

\author{
Richardson Kojo Edeme • Chigozie Nelson Nkalu* \\ Department of Economics, University of Nigeria, Nsukka, Nigeria
}

Received: 11 October 2018

Revised: 26 February 2019

Accepted: 28 February 2019

\begin{abstract}
Beyond the country-level impact, this study evaluates public expenditure in Nigeria in the last decade based on composition and distributional impacts on human development at the statelevel considering education, health, agriculture and rural development water resources energy, housing and environmental protection. Using data generated from 20 states from 2007-2017, the empirical analysis indicates that the efficacy of education, health, agriculture and rural development and water resources in improving human development is greater than that of energy, housing and environmental protection expenditure. More interestingly, the positive effect of capital expenditure is mitigated by increased recurrent expenditure. The combination of these factors strongly reduces the capability of public expenditure to foster human development. Based on the distributional impact assessment model, education, health, agriculture and rural development and water resources has positive marginal impact while energy, housing and environmental protection has negative marginal impact. Together, these results further advance the case for improving expenditure on the components and sectors that enhances human development. In other words, the public policy plays a great role in human development expenditure in Nigeria.
\end{abstract}

Keywords: public expenditure pattern; human development; distributional impact JEL Classification Codes: H51, H52, H75, 016

\section{Introduction}

Over the last two decades, many countries in low and medium-income countries have witnessed substantial improvement in economic growth. Despite significant progress in growth, two trends may be noticed. First, social indicators have differed between regions and between countries and secondly, income inequality has worsened between population groups within countries even though the human development index between countries has improved

\footnotetext{
*Corresponding author. E-mail: nelson.nkalu@unn.edu.ng.

Citation: Edeme, R. K., and Nkalu, C. N. (2019) Public Expenditure and Human Development in Nigeria in the last decade, composition and distributional impacts, Economics and Business Letters, 8(2), 62-73.
}

DOI: $10.17811 / \mathrm{ebl} \cdot 8.2 .2019 .62-73$ 
marginally. This is a manifestation that the ability of developing countries to reduce inequality, poverty and improve welfare may be threatened. Sen (2000), Hao and Fan (2001) contend that increase growth should enlarge the availability and widen the distribution of basic lifesustaining needs that should improve well-being through enhanced quality life as manifested in higher educational attainment, healthier life, sustainable environment and greater life expectancy. For the attainment of these goals, the international community has solicited developing countries to increase human development spending. In the face of improving the quality of life, inequality, unemployment and poverty reduction, public expenditure has therefore assumed increasing importance.

There is also growing concern of relying heavily on public expenditure as a means of improving human development. In line with this, different countries have carried out expenditure on some sectors to such an extent that one should expect positive correlation between progress in expenditure and human development. This optimism may, however, be suspected because despite growth in expenditure, the pace of human development has been slow and so far its growth has been slightly marginal and erratic. For instance, human development index (HDI) for Nigeria grew positively by 0.3 percent in 2007 but declined to $0.1 \%$ in 2008. From 2010-2013 and 2014-2017 it grew marginally by $0.2 \%$ and $1.7 \%$ respectively. For these years, expenditure grew by $4.7,8.4$ and $5.8 \%$ respectively.

With regard to capital expenditure share in total expenditure, the highest share of $42.7 \%$ was recorded in 2012 and was less than $15 \%$ between 1994 and1997. In 2003, it increased from $46.9 \%$ to $47.5 \%$ and remained between $47.5 \%$ and $47.7 \%$ from $2003-2008$. Thereafter, capital expenditure share in total expenditure rose to $48.2 \%$ in 2009 and remained between $48.2 \%$ and $38.6 \%$ from 2009-2011. This shows that a level of expenditure was maintained for average of three to four years before it improved marginally by $1 \%$. Meanwhile recurrent expenditure was pinned around $58.01 \%$ to $68.9 \%$ from 1999-2015 (CBN, 2017). Available statistics from World Development Report (2017) and UNDP (2018) depict that while the population of people in severe multidimensional poverty in the world increased by 25 percent between 2009 and 2015, the figure for Nigeria was averagely 54.8 percent. For the same period, life expectancy for the world averaged 73.8 while that of Nigeria averaged 53.4 while literacy rate for male and female was 79.9 and 65.3 respectively. Although there was a decrease in infant mortality rate from 87.9 in 2014 to 57.1 per 1, 000 live births in 2014, there was increase in population growth with deterioration in key environmental sustainability indicators. Indeed, population growth, economic growth and social development potentially increase the pressure on public expenditure.

From the above, it can be noted that each component of human development index is closely related to expenditure on various sectors. Thus we can say that public expenditure on social, economic and environmental protection in Nigeria plays an important role in ensuring sustainable human development. Even though considerable changes have occurred in Nigeria on different sectoral expenditure on human development in the last decade, there is lack of empirical evidence on the composition and its distributional impact on human development.

There is extensive literature on the relationship between public expenditure and human development, but the results are mixed and inconclusive, raising the importance of reassessing them. The economic literature shows a complex relationship between components of expenditure and human development. According to Patternosro, Rajaram and Tiogson (2007), public expenditure affects human development through its compositions or structure. A study by Edeme, Nkalu \& Ifelunini (2017), provide evidence that apart from its distributional impact, an increase in public expenditure improves the level of human development, all things being equal, since improved human development leads to healthier life and greater life expectancy. Apart from expenditure on the different sectors, the composition of such spending also affects human development. Indeed, the capital component tends to be more productive than the 
recurrent component. Since great changes take place in the expenditure pattern, part of the effect of public expenditure on human development reflects the distributional impact of the changing composition of expenditure. Expenditure on sectors which help to improve life, reduce poverty and increase employability and productivity are indirect but more assured and sustained way of improving human development (Mundle, 1998; Kaur and Misral, 2003; Omodero., 2019).

The economic growth literature has highlighted the consequences of poor budgetary allocation to human development sectors and economic performance. World Bank (2012) reports that the poor economic performance of developing countries can be linked to neglected human development. Empirically, Chakraborty (2003) have shown that public expenditure on education and health is invariably related to the level of human development attained by a country. Fan, Hazelland and Throat (2000) adopts different methods and country data to analyze the effects of public expenditure on human development and found that among the sectors, agriculture and rural development has positive effect on human development. Fan, Zhang and Zhang (2000) demonstrate that expenditure on health positively affect human development. A separate study in China reveals that education expenditure has the greatest impact on human development. Gordon (2008) found that expenditure on economic and community services have mix impact on human development, noticeable at various lag periods. The findings of Grammy and Assane (1996) also suggest that expenditure on education promotes human welfare. Others (Baldacci, Guin-Sui and deMello, 2004, inter-alia) shows that government expenditure has no impact on human development

Recurrent expenditure is generally viewed as a constraint on capital expenditure and human development. There is ample evidence of the depressing effect of recurrent expenditure and many researchers have corroborated its adverse effect on human. An increase in recurrent expenditure can dampen capital expenditure on rural development, agriculture and energy and could cause delay in capital flow in these sectors needed to generate sustainable growth in human development. A reduction in recurrent expenditure should therefore lead to increase in human development investment because resources would be made available to finance capital investment without necessarily reducing consumption or general welfare.

In this paper, we hypothesized that a high level of capital expenditure on education, health, agriculture, rural development, housing, energy and water resources accentuates human development. It has been asserted that transferring resources from capital to recurrent slowdowns human development. Empirical result on this matter in not clear. Also, while theories have also linked human development with environmental protection and housing, less attention has been paid to the possibility that human development could be explained by expenditure on these sectors. More importantly, the use of income per capita as a measure of human development has been faulted. As noted by World Bank (2016), eventhough many developing countries have experienced high gross national income per capita, it has not manifested in enhanced quality life for a greater proportion of the population.

This paper aims to highlight the relationship between expenditure on education, health, agriculture and rural development, housing, energy and water resources and human development, in terms of composition and distributional impact. We use panel data from 2007 to 2017 for 20 states and alternative econometric methods, panel least square and GMM (fixed effects estimator). Our results suggest that the efficacy of education, health, agriculture and rural development and water resources in improving human development is greater than that of energy, housing and environmental protection expenditure. More interestingly, the positive effect of capital expenditure is mitigated by increased recurrent expenditure. The combination of these factors strongly reduces the capability of public expenditure to foster human development. Based on the distributional impact assessment model, education, health, agriculture and rural development and water resources has positive marginal impact while energy, housing and environmental protection has negative marginal impact. Our results are robust and relevant by virtue of 
taking into account human development index and different components of human development.

The remainder of the paper is organized as follows. Section 2 attempt to show how public expenditure influences human development. Section 3 derives estimating equations and shows results and section 4 is devoted to the conclusion.

\section{How may Public Expenditure influence Human Development?}

In this section, we highlight the theoretical arguments linking public expenditure and human development. First, public expenditure should promote human development because it is a means of opening people's capabilities, improve productivity and make life more abundant. It is also argued that public expenditure on economic, social and environmental sectors reduces poverty, and contributes to healthy living and political participation.

In Global Environment Outlook-5 (UNEP 2012), education has been considered as a vehicle for sustainable human development. Education increase people's ability to contribute more to the development process and improve their level of productivity. Education guarantees people to live longer and healthier life, become knowledgeable and improve environmental quality. Some authors like Jung and Thorbecke (2003) show that education expenditure have positive impact on human development, while Castro-Leal, et al (1999) conclude that education expenditure have negative impact on human development. Health expenditure plays a great role in the health status of a society by lowering the effective price of health-enhancing inputs to create conducive environment for healthy living. Public spending on health care is justified by increase in welfare that accrues from a reduction in the burden of disease, particularly because of large spillover benefits. Jose (2005) shows that health expenditure is positively related to human development. WHO/FAO (1991) postulate that agriculture ensures food sufficiency that is necessary for human development. Sahn and Younger (1999) found that agriculture have negative long-term effect on human development. Rural development is also imperative in human development because it could have immediate and lagged effects on human development. As immediate effect, employment opportunities are created specifically among the poor. As lagged effect on income through increased productivity and expands trade. Higher income may then promote human development through better health and higher educational attainment, which ultimately, raises the earning potential of individuals.

Environmental protection leads to low environmental degradation which fosters human activities in agriculture, housing and related activities that are capable of improving human life. This was aptly demonstrated by Adrian and Nadkarni (2001) in a study on the relationship between environmental protection and human development. It was found that have shown that environmental protection is positively related with human development. Closely related, Chakraborty (2003) finds positive relationship between per capita health and education expenditure and human development while others shows that capital education expenditure is negatively correlated with human development. Although Vaclav (2007) demonstrated that energy is indispensable in human development, that there is still energy crises in developing countries, especially in rural areas which is inhibiting human development efforts. Fan, Zhang and Zhang $(2000 ; 2002)$ found that expenditure on education, rural infrastructure and health have visible positive impact on human development. Apart from the fact that expenditure on water resources is helps to meet demands for food and energy, it is also helpful in accessing capacity for health care. Therefore, we expect expenditure on water resources to have positive effect on human development. Oluwatobi (2011) found that capital expenditure and human development is negative while increase in recurrent expenditure has positive growth effect on human development. 


\section{Empirical analysis}

This paper seeks to analyze the effect of capital and recurrent expenditure and their distributional impact on human development. We follow Feyzioglu, Swaroop and Zhu (2000) and Chakraborty (2003) who developed a model linking public expenditure and human development. However, due to the heterogeneity nature of Nigeria, we assume that each state differs in revenue and this explains their ability to spend on human development.

\subsection{Economic specifications}

The review of literature identifies two expenditure channels of transmission of effect of public expenditure on human development. These are capital and recurrent expenditures. Firstly, we estimate level of human development on per capital and recurrent expenditure on different sectors. The base line model is specified as:

$$
\begin{aligned}
& H D I_{i, t}=\omega_{i}+\omega_{2} C E s_{i, t}+\omega_{3} H T_{i, t}+\varnothing_{t}+\alpha_{i}+\rho X_{i, t}+e_{i, t} \\
& H D I_{i, t}=\beta_{i}+\beta_{2} R E s_{i, t}+\beta_{3} H T_{i, t}+\varnothing_{t}+\alpha_{i}+\rho X_{i, t}+e_{i, t}
\end{aligned}
$$

where $H D I_{i, t}$ is human development index in state $i$ over a period, $t$. $C E s_{i, t}$ and $R E s_{i, t}$ is respective capital and recurrent expenditure on selected sectors, $\varnothing_{t}$ denotes time effect while $\alpha_{i}$ represents state's specific effect, $X_{i, t}$ is a vector of control variables.

Considering the sectors under focus, the model for estimation is specified as:

$$
\begin{gathered}
H D I_{i t}=\varphi_{1}+\varphi_{2} C E / T E_{2 i t}+\varphi_{3} C H / T E_{3 i t}+\varphi_{4} C A / T E_{4 i t}+\varphi_{6} C N / T E_{6 i t}+\varphi_{7} C S / T E_{7 i t}+ \\
\varphi_{8} C P / T E_{8 i t}+\varphi_{9} C W / T E_{9 i t}+U_{i t} \\
H D I_{i t}=\beta_{1}+\beta_{2} R E / T E_{2 i t}+\beta_{3} R H / T E_{3 i t}+\beta_{4} R A / T E_{4 i t}+\beta_{6} R N / T E_{6 i t}+\beta_{7} R S / T E_{7 i t}+ \\
\beta_{8} R P / T E_{8 i t}+\beta_{9} R W / T E_{9 i t}+U_{i t}
\end{gathered}
$$

where $H D$ : human development, $C E / T E$ : per education capital expenditure, $C H / T E$ : per health capital expenditure, $C A / T E$ : per agriculture and rural development capital expenditure $C P / T E$ : per environmental protection capital expenditure, $C R / T E$ : per capital expenditure on energy, $C S / T E$ : per capital expenditure on housing, $C W / T E$ : per capital expenditure on water resources, $R E / T E$ : per education recurrent expenditure, $R H / T E$ : per health recurrent expenditure, $R A / T E$ per agriculture and rural development recurrent expenditure, $R N / T E$ : per energy recurrent expenditure, $R P / T E$ : per environmental protection recurrent expenditure, $P E / T E$ : per education expenditure, $P H / T E$ : per health expenditure, and $P A / T E$ : per agriculture and rural development expenditure.

The effect of public expenditure on different components of human development index can be estimated respectively as:

$$
\begin{gathered}
L E B_{i, t}=\varphi_{1}+\varphi_{2} C P U X_{2 i, t}+U_{i, t} \\
E D U_{i, t}=\varphi_{1}+\varphi_{2} C P U X_{2 i, t}+U_{i, t} \\
L Y_{t, t}=\varphi_{1}+\varphi_{2} C P E X_{2 i, t}+U_{i, t}
\end{gathered}
$$

where $L E B$ : life expectancy, $E D U$ : education (measured as average years of schooling in total the population), $L Y$ : income (measured as per capita income), and $C P U X$ : combined public expenditure on human development.

The distributional impact model borrows from the distributional assessment model employed in assessing the distributional impact of government expenditure on poverty reduction. As Deaton and Paxson (1997) emphasized, the impact of public expenditure should be evaluated based the changes emanating from such expenditure. In particular, budgetary decisions for a given sector for a given year are generally made on the basis of their impact in the previous year. Given the focus of our study, relationship between the changes in human development in relation to change in public expenditure can be expressed as: 


$$
\partial H^{h}=\sum^{n} \underline{R}_{i t} i \partial l_{-} \Sigma(i=1) s_{i t} i
$$

where $i=$ selected sectors, $\partial=$ first difference. Equation (8) explicitly shows that distributional impact of expenditure on human development must derive from changes in expenditure across different sectors but did not account for the distributional impact, which is usually treated on differenced values. Differencing the variables therefore allows for the analysis of the impact of changes in public expenditure on human development. In view of the panel analysis, model for the distributional impact can be specified as:

$$
\begin{gathered}
\partial H D i, t=\gamma_{o}+\mu \partial P E / T E_{i, t-1}+\rho \partial P H / T E_{i t-1}+\ell \partial A P / T E_{i, t-1}+v \partial P N / T E_{i, t-1}+\zeta \partial P S / T E_{i, t-} \\
1+\eta \partial P P / T E_{i, t} Q \partial P W / T E_{i t}+U_{i t}
\end{gathered}
$$

where $P N / T E$ : energy expenditure, $P S / T E$ : housing expenditure, PP/TE: environmental protection expenditure, $P W / T E$ : water resources expenditure, $\triangle$ : first difference operator, $\gamma_{o}, \varphi_{1}$, $\beta_{1}$ : specific country effect. The period considered, $2007-2017$, is taken from 20 states.

\subsubsection{Estimation techniques}

Equations (3)-(7) can be estimated using ordinary least square (OLS). However, OLS is inappropraite because it does not take into account unobserved heterogeneity of different states. This may make the estimates to be biased. To over come this, we use panel least square method considering the two principle alternative: fixed effects (FE) or random effects (RE). The Hausman test is used to check the validity of results, where the null hypothesis is that the instrumental variables are uncorrelated with the residual and the serial correlation test $g^{2}(X)$. Since Equation (7) is a first-differenced model, we rely on Generalized Method of Moments (GMM) system estimators following Arellano and Bond (1991). The essence of this is to remove unobserved time invariant country specific effects, and then instrument the right-handside variables in the first-differenced equations. The first-differenced generalized method of moment estimators when applied to panel data models help to overcome the problem of the potential endogeneity of some independent variables, measurement errors and omitted variables. To ensure a parsimonious use of instruments, we do not employ more instruments than the number of countries included in our regressions. The addition of more instruments alters the validity of the instruments and leads to the problem of overestimation instrumented variables.

For robustness of result, we estimate the impact of public on each component of human development index (life expectancy, education and income) before used for further estimation.

\subsection{Descriptive analysis of data}

In this study, we capture human development by human development index (HDI). The HDI is an indicator of the attainment of human well being measure the achievement that represents dimensions in human development: health, education and income. The data on human development index come from UNDP Human Development Report (2016) while data on expenditure was generated from World Development Indicators, Accountant Generals, Report and Central Bank of Nigeria Annual Reports and Statement of Accounts (Various Years). In line with other studies, data on expenditure (which comprises of recurrent and capital components) are expressed as percentage of total expenditure.

Table 1 present descriptive statistics relating to human development indices, capital and recurrent expenditure, according to level of development. It shows a low annual average growth of human development index for world (0.74) in contrast to that of developing countries (1. $05)$. The developing countries with the lowest health expenditure had higher growth in human development index (1.05). We also noticed that developing countries had relatively lower education expenditure. Nigeria with low expenditure on education and health recorded considerable growth in human development (1.54) compared to world growth of 0.64 . 


\subsection{Results}

Table 2 present the results of the impact of public expenditure on different components of human development index in Nigeria (Fixed Effects).

Table 1. Descriptive statistics of human development index and public expenditure according to level of development.

\begin{tabular}{lrrrr}
\hline \hline & Average & $\begin{array}{r}\text { Std } \\
\text { Deviation }\end{array}$ & Minimum & Maximum \\
\hline World & \multicolumn{3}{c}{} & \\
\hline Growth in HDI & 0.74 & 2.54 & 0.69 & 0.78 \\
HDI & 0.64 & 0.02 & 0.54 & 0.77 \\
Education expenditure & 5.0 & 2.4 & 3.7 & 14.1 \\
Health expenditure & 6.0 & 1.8 & 5.3 & 16.4 \\
Env. protection & 2.0 & 3.4 & 1.0 & 9.1 \\
expenditure & & & & \\
\hline Developing countries & & & & 1.80 \\
\hline Growth in HDI & 1.05 & 0.92 & 0.99 & 0.98 \\
HDI & 0.51 & 0.48 & 0.22 & 2.9 \\
Education expenditure & 1.7 & 0.9 & 0.2 & 5.6 \\
Health expenditure & 3.0 & 2.8 & 1.7 & 5,2 \\
Env. protection & 1.2 & 2.3 & 1.0 & \\
expenditure & & & & 1.81 \\
\hline Nigeria & & & & 1.88 \\
\hline Growth in HDI & 1.54 & 0.09 & 0.09 & 4.5 \\
HDI & 1.08 & 1.28 & 0.91 & 0.91 \\
Education expenditure & 3.1 & 2.1 & 0.09 & 0.50 \\
Health expenditure & 0.9 & 0.03 & 0.02 & \\
Env. protection & 0.4 & 0.2 & 0.34 & \\
expenditure & & & & \\
\hline \hline
\end{tabular}

Table 2. Results of the impact of public expenditure on different components of human development index in Nigeria (Fixed Effects).

\begin{tabular}{lrrr}
\hline \hline & Life expectancy & Education & Income \\
\hline Combined public & 0.043 & 0.065 & 0.008 \\
expenditure & $(2.07)^{* *}$ & $(0.95)^{*}$ & $(0,54)^{*}$ \\
Constant & -1.39 & -1.23 & -0.045 \\
& $(1.72)$ & $(-0.88)$ & $(1.26)^{*}$ \\
Observations & 230 & 230 & 230 \\
AR(2) p-value & 0.20 & 0.75 & 0.34 \\
Hausman Test p & 0.32 & 0.49 & 0.62 \\
value & & & \\
\hline \hline
\end{tabular}

Note: Figures in parentheses are t- statistics $*$ Significant at 1 percent level, $* *$ Significant at 5 percent level. Source: Authors' calculations.

The result in Table 2 shows that combined public expenditure on education, health, agriculture and rural development, environmental protection, energy, housing and water resources has positive relationship with the various components of human development index. The coefficients indicate that a rise in public expenditure could lead to $0.043,0.065$ and 0.008 percentage 
increase in life expectancy, education and income respectively. To ensure that there is no variation on the effect, the robustness of the result is checked by relating different components of public expenditure with normalized human development index.

The results in Table 3 provide evidence that education, health, rural development energy, housing, environmental protection and water resources expenditure is positively correlated with human development. The result suggests that the efficacy of education, health, agriculture and rural development and water resources expenditure in improving human development is greater than that of energy, housing and environmental protection expenditure. The role of environmental protection, housing and energy as fundamental sources in human development highlighted by the economic literature, leads us to question the possibility that the effect of environmental protection on human development could differ according to the level of expenditure carried out. Although environmental protection, energy and housing are important determinant of human development in developing and government in these countries are not overly concerned with environmental, housing and energy problems. These results differ from previous studies who find that expenditure on education, health and environmental protection has significant positive effect on human development. In essence, Zhang and Zhang (2002) conclude that education improves human development, whereas World Bank (2003) finds the opposite result.

Table 3. Effect of public expenditure on human development (Fixed Effects).

\begin{tabular}{lr}
\hline Education expenditure & 0.034 \\
Health expenditure & $(2.540)^{*}$ \\
& 0.025 \\
Agric. \& rural dev expenditure & $(1.483)^{*}$ \\
& $0.021^{*}$ \\
Energy expenditure & $(2.168)$ \\
& 0.010 \\
Housing expenditure & $(0.235)$ \\
& 0.003 \\
Env. protection expenditure & $(0.027)$ \\
& 0.009 \\
Water resources expenditure & $(0.024)$ \\
& 0.0013 \\
\hline AR(2) p-value & $(0.022)$ \\
Hausman Test p value & 0.53 \\
\hline Observations & 0.32 \\
\hline \hline
\end{tabular}

Note: Figures in parentheses are t-statistics, *indicate significant at $1 \%, * *$ significant at 5\%. Source: Authors' Calculations.

Table 4 presents the result of the effect of recurrent expenditure on human development. Regarding the expenditure component, recurrent expenditure has positive and negative effects on human development. The positive effect of recurrent expenditure could be attributed to large size set aside for such during the period under consideration. In essence, increase in recurrent expenditure can dampen capital expenditure on energy, housing, agriculture and rural development and cause delay in capital flow needed to generate sustainable growth in human development. The effect of capital expenditure on human development as presented in Table 5 shows that human development increases with capital education, health, agriculture, agric and rural development, environmental protection and water resources expenditure and decreases with capital energy and housing expenditure. The result collaborates Chakraborthy (2003) in terms education and health. The positive effect of capital education, health, agriculture, agriculture and rural development, environmental protection and water resources expenditure on human 
development is not surprising because such expenditure help in capital formation which could transform to better human development indicators. The results also suggest that capital expenditure on energy and housing, though important for infrastructural development, they may not necessarily guarantee improvement in human development.

Table 4. Effect of recurrent expenditure on human development (Fixed Effects).

\begin{tabular}{lr}
\hline Recurrent expenditure on education & 0.002 \\
Recurrent expenditure on health & $(-0.977)^{*}$ \\
& -0.008 \\
Recurrent expenditure on agric. \& & $(-1.354)^{*}$ \\
rural development & -0.004 \\
Recurrent expenditure on energy & $(0.492)^{*}$ \\
& 0.004 \\
Recurrent expenditure on housing & $(1.360)$ \\
& -0.002 \\
Recurrent expenditure on energy & $(-0.307)$ \\
& 0.013 \\
Recurrent expenditure on water & $(0.89)$ \\
resources & 0.012 \\
\hline AR(2) p-value & $(-1.34)$ \\
Hausman Test p value & 0.31 \\
\hline Observations & 0.42 \\
\hline \hline
\end{tabular}

Note: Figures in parentheses are t-statistics, *indicate significant at $1 \%, * *$ significant at 5\%. Source: Authors' Calculations.

Table 5. Effect of capital expenditure on human development (Fixed Effects).

\begin{tabular}{lr}
\hline Capital expenditure on education & 0.001 \\
Capital expenditure on health & $(1.712)^{*}$ \\
& 0.011 \\
Capital expenditure on agric. \& rural & $(2.043)^{* *}$ \\
development & 0.004 \\
Capital expenditure on energy & $(1.52)^{*}$ \\
& -0.001 \\
Capital expenditure on housing & $(0.326)$ \\
& -0.001 \\
Capital expenditure on energy & $(-1.960)^{*}$ \\
& 0.001 \\
Capital expenditure on water resources & $(0.320)$ \\
& 0.001 \\
AR(2) p-value & $(1.53)^{*}$ \\
Hausman test (p- value $)$ & 0.40 \\
\hline Observations & 0.49 \\
\hline \hline
\end{tabular}

Note: Figures in parentheses are t-statistics, *indicate significant at $1 \%, * *$ significant at $5 \%$. Source: Authors' Calculations.

The result of the distributional impact of public expenditure on human development reported in Table 6 show that an increase in education, health, water resources, agriculture and rural development expenditure increase human development by $0.03,0.01,0.05$ and 0.01 respectively. If education, health, water resources, agriculture, rural development expenditure reduces, 
it then implies that growth in human development decreases. Also, an increase in energy, housing, environmental protection expenditure leads to reduction in human development. The negative coefficient of $0.08,0.09$ and 0.05 for energy, housing and environmental protection implies that the level of expenditure and investment made on energy housing and environmental protection is minimal.

Table 6. Distributional impact of public expenditure on human development (Fixed Effects).

\begin{tabular}{|c|c|}
\hline$\Delta E d u c a t i o n$ expenditure & $\begin{array}{r}0.003 \\
(1.37)\end{array}$ \\
\hline$\Delta$ Health expenditure & $\begin{array}{r}0.001 \\
(2.111)\end{array}$ \\
\hline$\Delta$ Agric \& rural dev expenditure & $\begin{array}{l}0.0051 \\
(0.123)\end{array}$ \\
\hline$\Delta E n e r g y$ expenditure & $\begin{array}{r}-0.091 \\
(-0.051)\end{array}$ \\
\hline DHousing expenditure & $\begin{array}{r}-0.079 \\
(0.090)\end{array}$ \\
\hline$\Delta E n v i r$ protection expenditure & $\begin{array}{l}-0.0046 \\
(-0.134)\end{array}$ \\
\hline$\Delta W a t e r$ resources expenditure & $\begin{array}{r}0.001 \\
(0.061)\end{array}$ \\
\hline $\begin{array}{l}\text { AR(2) p-value } \\
\text { Hausman Test p value }\end{array}$ & $\begin{array}{l}0.51 \\
0.32\end{array}$ \\
\hline Observations & 260 \\
\hline
\end{tabular}

Note: Figures in parentheses are t-statistics, *indicate significant at $1 \%$, **significant at 5\%. Source: Authors' Calculations.

\section{Concluding remarks}

Discussions on human development have exposed the importance of translating explosive growth in public expenditure on social, economic and environmental protection into a better scale in human development. They also encourage benefit inherent in the budgetary allocation to the different sectors in relation to its impact in the previous years. The current study provide analysis of the impact of various composition of public expenditure and distributional impact on human development in the last decade, using data from 2007-2017 generated from 20 states in Nigeria. The study found that the efficacy of education, health, agriculture and rural development and water resources in improving human development is greater than that of energy, housing and environmental protection expenditure. More interestingly, the positive effect of capital expenditure is mitigated by increased recurrent expenditure. The combination of these factors strongly reduces the capability of public expenditure to foster human development. Based on the distributional impact assessment, it was found that an increase in education, health, water resources, agriculture and rural development expenditure increase human development. If education, health, water resources, agriculture, rural development expenditure reduces, it then implies that growth in human development decreases. The negative effect for energy, housing and environmental protection implies that the level of investment and innovation made on energy housing and environmental protection is minimal. The intuition behind the findings is that although expenditure has been carried out on energy, housing and environmental protection towards improving human development, further spending on these sectors seems to have negligible impact while more capital expenditure on education, health, agriculture, rural development and water resources may open up more opportunities that could accelerate human 
development. Together, these results further advance the case for improving expenditure on the components and sectors that enhances human development. In other words, the public policy plays a great role in human development expenditure in Nigeria.

\section{References}

Adrian, G., and Nadkami, P. O. (2001) Protecting the environment for human development, a four country study: Botswana, Ghana, Honduras and Senegal, ESMAP Technical Paper, March.

Arellano, M., and Bond, S. (1991) Some Tests of Specification for Panel Data: Monte Carlo Evidence and an Application to Employment Equations, Review of Economic Studies, 8(2), 277-297.

Baldacct, E., Guin-Sui, M. T., and DeMello, L. (2004) More on the Effectiveness of Public Spending on Health care and Education: A Covariance Structure Model, Journal of International Development, 15(6), 709-725.

Central Bank of Nigeria (2017) Statistical Bulletin, Central Bank of Nigeria, Abuja.

Chakraborty, L. (2003) Public Expenditure and Human Development: An empirical in vestigation. Paper Presented at Wider International Conference on Inequality, Poverty and Human Well-Being, Helsinki, 30-31 May.

Castro- Leal, Dayton, J., Demery, L and Mehra, K. (1999) Public social spending in Africa: Do the poor benefit? The World Bank Observer, 14 (1).

Deaton A., and Paxson, C. (1998) Distributional impact of government expenditure and Pov erty: Evidence from panel data. Journal of Political Economy 106 (5).

Edeme, R. K., N. C Nkalu and Ifelunini, I. A. (2017) Distributional impact of public expenditure on human development in Nigeria, International Journal of Social Economics, 44 (12), 1683-1693, https://www.emeraldinsight.com/doi/full/10.1108/IJSE-05-2016-0152.

Fan, S., Hazelland, P and Throat, S. (2000) Linkage between government spending, human development and poverty in rural India, IFPRI Research Report, 110, Washington, D.C.

Fan, S., Zhang, L and Zhang, X. (2002) Growth, inequality and poverty in rural China: The role of public expenditure, IFPRI Research Report, 125, Washington D.C.

Feyzioglu, T., V. Swaroop and Zhu, M. (2000) Modeling the determinant of Human devel opment expenditure in Sub- Saharan African, Journal of African Economy 6, 29-58.

Gordon, S (2008) Analyzing the patterns of government expenditure in Canada. Canadian Public Administration, 101-120.

Grammy, A.S., and Assane, D. (1996) Evidence of the effect of education expenditure on household welfare. Applied Economic Letters, 4, 121-124.

Hao, E., and J. Fan (2001) Design and Implementation of the Vietnam Human Development Programmes- the Poor or the Shocked'? World Bank Policy Research Working Paper No 2436, Washington, D.C.

Jose, A. O (2005) Income distribution, poverty and social expenditure in Latin America. Conference of the Americans, Washington D.C.

Jung, H. S., and Thorbecke, E. (2003) The impact of public expenditure on human development and poverty reduction in Tanzania and Zambia: A General equilibrium Approach, Journal of Policy Modeling, 25 (8), 701-725.

Kaur, B., and Misral, S. (2003), Social sector expenditure and human attainments: An analysis

of Indian States. Reserve Bank of India Occasional Papers. Summer-Monsoon 24 (1-2): $105-145$

Mundle, S (1998) Financing human development: some lesson from advanced Asian coun tries. World Development, 26 (4), 659-67. 
Oluwatobi, S. O. (2011) Government expenditure on human capital development: Implica tions for economic growth in Nigeria, Journal of Sustainable Development, 4 (3), $72-80$.

Omodero., C. O (2019), Government general spending and human development: A case study of Nigeria, Academic Journal of Interdisciplinary Studies, 8(1),51-59, Doi: 10.2478/ajis- 2019-0005.

Patternosro,S., A. Rajaram and Tiogson, E. R. (2007) How does the composition of public spending Matter?, Oxford Development Studies, 35 (1), 48-82.

Sahn, D. E., and Younger, S. (1999) Social sector expenditures and human development in Africa. Working Paper 99/172. Fiscal Affairs Department, International Monetary Fund.

Sen, A. K. (2000) A decade of human development, Journal of Human Development, 1 (1), $17-23$.

UNDP (2018).Human development index trends, 1990-2017. Human Development Report Office (HDRO), United Nations Development Programme, available at http://hdr.undp.org/.

UNEP (2012) Global environment outlook 5 (GEO 5), available at http://www.earthprint.com/productfocus.php?id=DEW/1417/NA.

Vaclcav, S. (2007) Energy and sustainable development. UNDP study on energy, Working Paper.

WHO (World Health Organization)/FAO (Food and Agriculture Organization of the United Nations)/UNU (United Nation University) Expert Panel Report (1991) Food, Energy and Protein Requirement. WHO Technical Report No. 724.

World Development Indicators (2017) World Development Indicators Data, available at www.worldbank.org/data.

World Bank (2003) World Development Report 2003: Sustainable development in a dynamic World, available at https://openknowledge.worldbank.org/handle/10986/5985.

World Bank (2016). World Development Report 2016: Digital Dividends, available at https://www.worldbank.org/en/publication/wdr2016.

Appendix A. States included in the study.

\begin{tabular}{llllll}
\hline \hline $\begin{array}{l}\text { North } \\
\text { West Zone }\end{array}$ & $\begin{array}{l}\text { North East } \\
\text { Zone }\end{array}$ & $\begin{array}{l}\text { North } \\
\text { Central Zone }\end{array}$ & $\begin{array}{l}\text { South East } \\
\text { Zone }\end{array}$ & $\begin{array}{l}\text { South } \\
\text { South Zone }\end{array}$ & $\begin{array}{l}\text { South West } \\
\text { Zone }\end{array}$ \\
\hline Kaduna & Adamawa & Niger & Anambra & Delta & Oyo \\
Kebbi & Bauchi & Kogi & Imo & Akwa & Lagos \\
Jigawa & Borno & Plateau & Enugu & Ibom, & Ondo \\
& & & & Cross River & Ekiti \\
& & & Edo & \\
\hline \hline
\end{tabular}

